\title{
Bitlis İlinde Rutin Olarak Diyaliz Ünitesine Bağlanan Diyaliz Hastalarının Sıkıntı Durumlarının Belirlenmesi
}

\author{
Aziz AKSOY ${ }^{1 *}$, Seda OĞUR ${ }^{2}$ \\ ${ }^{1}$ Bitlis Eren Üniversitesi, Sağllk Yüksekokulu, Beslenme ve Diyetetik Bölümü, Rahva Yerleşkesi, Bitlis
}

\begin{abstract}
Özet
$\mathrm{Bu}$ çalıșma diyaliz ünitesine rutin olarak bağlanan diyaliz hastalarının sosyal ve psikolojik sıkıntı durumlarını belirlemek için yürütülmüştür. Anket şeklinde hazırlanan 26 soru ile hastaların diyaliz ünitesine bağlanırken yaşadıkları sıkıntı durumları hakkındaki görüş ve düşüncelerini, diyaliz ile ilgili farkındalıklarını ortaya koymak amaçlanmıştır. Yürütülen çalışma Bitlis Devlet Hastanesi ve Tatvan Devlet Hastanesi'nde toplam 70 diyaliz hastası ile yapılan anket çalıșmasının sonuçlarını içermektedir. Elde edilen verilerin istatistiksel analizi IBM SPSS Statistics $20 \circledR$ Paket Programılla Ki-kare ve Sıklık testleri uygulanarak yapılmıştır. Elde edilen istatistiksel bulgulara göre; hastaların medeni hali ile böbrek nakli için yeterli girişimlerde bulunma durumları, ailesinin maddi destek sağlarken yaşadığı sıkıntı durumları, hastalık nedeni ile sosyal aktivitelerde kısıtllılı ve aile içi ilișkilerde sorun yașama durumları arasında önemli farklılık olmadığı $(\mathrm{p}>0.05)$ görülmüștür. Cinsiyet ile aile içi ilişkilerde sorun yaşanması arasındaki farkın anlamlı $(\mathrm{p}<0.05)$ olduğu bulunmuştur. Hastalıklarını öğrendikten sonra hastaların \%27.1'i profesyonel destek almıştır. Hastalıklarını ilk öğrendiklerinde ise; \%18.6'sı umutsuzluğa kapılmış, \%15.7'si gelecek kaygısı yaşamış, \%8.6'sı inanamamış, \%18.6'sı kabullenememiş, \%8.6'sı hiçbir şey hissetmemiş, \%2.9'u şok yaşamış, \%10.0'u çok üzülmüş, \%15.7'si kabullenmiş ve \%1.4' ü de hastalığının ne olduğunu merak etmiştir. Hastaların büyük bir kısmının diyaliz merkezine giderken ulaşımda sıkıntı çekmedikleri belirlenmiştir. Sonuç olarak; diyalize bağlandıkları sürece, hastaların \%48.6'sının hiçbir

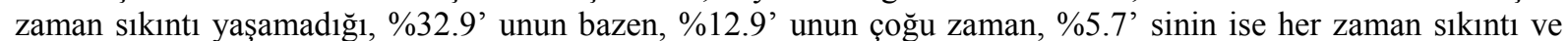
dışlanma durumu yaşadığı anlaşııııışır.
\end{abstract}

Anahtar Kelimeler: Kronik böbrek hastası, diyalize bağlanma, sıkıntı durumu

\section{Determination of Patients' Hardships Connected to the Dialysis Unit Routinely in Bitlis, Turkey}

\begin{abstract}
This study was conducted to determine social, medical and psychological hardships of dialysis patients connected to the dialysis unit routinely. The study was aimed to reveal with 26 questions prepared in the form of questionnaire, their opinions and thoughts related to hardships when connecting to dialysis unit and awareness on dialysis. The study was included statistical results of the survey conducted with a total of 70 dialysis patients in Bitlis State Hospital and Tatvan State Hospital. Statistical evaluation of the data was made with IBM SPSS Statistics $20 \AA$ Software Packages Program by applying Chi-square and Frequencies tests. According to statistical analysis results, it was seen that the difference was insignificant ( $p>0.05)$ between the marital status of patients and the status of them in sufficient attempt to kidney transplation, the distress living status of their family while providing financial support, limitations status on social activities because of illness, problem living status in family relationships. The significant difference $(\mathrm{p}<0.05)$ was found between sex and live a problem in family relationship. After they learned their disease, $27.1 \%$ of them received professional support. When they first learned of the illness, $18.6 \%$ of them were despondent, $15.7 \%$ of them lived future anxiety, $8.6 \%$ of them couldn't believe, $18.6 \%$ of them couldn't accept, $8.6 \%$ of them were nothing feeling, $2.9 \%$ of them lived shock, $10.0 \%$ of them were very upset, $15.7 \%$ of them accepted and $1.4 \%$ of them has also wondered what this disease. It is determined that a large proportion of patients didn't distress in transportation when going to dialysis center. As a conclusion as long as dialysis patients were connected to dialysis unit, it was understood that $48.6 \%$ of them
\end{abstract}

"Sorumlu Yazar: aksoy_aziz@hotmail.com 
never have lived distress, $32.9 \%$ of them sometimes have lived distress, $12.9 \%$ of them most of the time has lived distress, $5.7 \%$ of them every time have lived distress and excluded by the society.

Keywords: Chronic kidney patient, connecting to dialysis, distress situation

\section{Giriş}

Akut böbrek ve kronik böbrek yetmezliği, diüretiğe cevap vermeyen kronik kalp yetersizliği, ilaç intoksikasyonları ve psoriasis hemodiyaliz endikasyonlarıdır [1]. Kreatinin klirensi $0.1-0.15 \mathrm{ml} / \mathrm{dk} / \mathrm{kg}$ seviyesine düştüğünde kronik diyaliz tedavisi başlatılmalıdır [2]. Diyaliz tedavisinin hemodiyaliz ve periton diyalizi olmak üzere iki şekli vardır [3].

Hemodiyaliz (HD), hastadan alınan kanın, çihaz yardımıyla yarı geçirgen bir membrandan süzülerek ters yönden gelen diyalizat ile homojenize edilmesi ve difüzyon, ozmoz ve ultra filtrasyon ile asit- baz, elektrolit ve toksik madde bakımından düzenlenerek hastaya geri verilmesi işlemidir [4].

Periton Diyalizi, periton boşluğunu sınırlayan bir seröz zardır [5]. Periton zarı gibi doğal bir membranla herhangi bir kuvvete veya cihaza ihtiyaç duyulmadan böbrek fonksiyonlarını yerine koyma yöntemidir. Karın boşluğunda çözelti ve su absorbsiyonu periton zarında mevcut olan kapiller dolaşım ve lenfatikler yardımıyla olur [6]. Periton diyalizi tekniğinde amaç, vücuttan ozmotik yolla uzaklaşması hedeflenen maddeleri kapsayan veya kandaki konsantrasyondan daha düşük oranda içeren, uzaklaştırılması istenmeyen maddeleri ise kandaki miktarıyla aynı oranda içeren steril bir diyaliz solüsyonunun periton boşluğu içine emniyetli bir teknikle doldurmak, ozmotik eşitlenmenin sağlanmasına yetecek kadar uzun bir süre periton boşluğunda bekletmek, daha sonra bu sıvıyı vücuttan uzaklaştırarak bu işlemi gerektiği sürece tekrarlanmaktır [7].

Periton diyalizi, son dönem böbrek yetmezliği olan hastalarda alternatif tedavi yöntemlerinden birisidir ve son yıllarda ülkemizde giderek artan sayıda hastaya uygulanmaktadır. Periton kapillerlerindeki kan ve diyalizat arasında çözeltilerin difüzyonu ve hipertonik solüsyonların periton boşluğuna ultrafiltrasyona yol açmaları, peritonun bir diyaliz membranı olarak kullanılmasının esaslarını oluşturmaktadır [8].

Bu çalışmada Bitlis Devlet Hastanesi ve Tatvan Devlet Hastanesi'nde rutin olarak diyalize bağlanan 70 hastanın sosyal sıkıntı durumları, hastalıkları ile aile içi kabullenme problemleri, sosyal çevrede karşılaştıkları zorluklar ve evlilik yaşantıları ile ilgili sıkıntı durumları, anket şeklinde hazırlanan 26 soru ile değerlendirmeye çalışılmıştır.

\subsection{Kronik Böbrek Yetmezliği (KBY)}

Kronik böbrek yetmezliği, hasta böbreğin vücut sıvılarının dengesini sürdüremeyecek şekilde ilerleyici ve geriye dönüşümsüz olarak bozulması olup, glomerül filtrasyon oranının (Glomerular Filtration Rate: GFR) böbrek fonksiyonlarında tespit edilebilir düzeyde değişikliklere neden olacak kadar kalıcı bir şekilde azaldığı durum olarak da tanımlanabilir. Bu durum genellikle GFR 25 ml/dakika'nın altına indiğinde ortaya çıkar. GFR normalin \%75'i kadar azaldığında buna sebep olan hasar ortadan kaldırılsa bile böbrek fonksiyonlarındaki bozulma kaçınılmaz olarak devam eder [9]. Böbrek işlevlerinin bozulması sonucu nefrotoksik etkisi olan üre, ürik asit, kreatinin gibi protein metabolitleri ile sodyum, potasyum, fosfor, gibi elementlerin kandaki konsantrasyonları yükselerek kardiyovasküler sistem, böbreklerin sentez ve metabolize etme kapasitesi bozulur.

KBY dünya nüfusunun yaklaşık olarak \%5-10'unu etkileyen toplumsal bir sağlık problemidir $[10,11]$. Türkiye'de erişkinlerde prevalansı \%15.7 saptanmış olup gün geçtikçe artan son dönem böbrek yetmezliği (SDBY) prevalansı ve olumsuz sonlanımları göz önüne alındığında günümüzdeki 
önemi giderek artmaktadır $[12,13]$. KBY' de fiziksel gücün ve dayanıklılığın kaybedilmesi, hissedilen ölüm korkusu, ekonomik güçlüklerin yaşanması, diyet, sıvı alımının kısıtlanması ve tıbbi tedaviye bağımlılık bu hastalığın aşırı bir stresör olarak algılanmasına neden olabilmekte, hastalığın aile ve evlilik yaşamında yol açtığı değişimler de yaşanan stres yönünü arttırmaktadır [15].

KBY olan hastaların tedavisinde en sık kullanılan tedavi yöntemlerinden biri olan diyaliz tedavisi, hastaları ölümden kurtarıp, yaşama devam etmelerini sağlamakla birlikte, fiziksel, psikolojik, sosyal ve ekonomik sorunları da beraberinde getirmektedir [16].

\subsection{Kronik Böbrek Hastalığının Epidemiyolojisi, Etiyolojisi ve Patofizyolojisi}

Epidemiyolojik çalışma sonuçlarına göre dünyada KBY oranları \%10-16, mikroalbuminüri oranları ise \%6-14 arasında saptanmıştır. KBY taramasında kullanılan testlerdeki kısıtlılıklar ve toplumda GFR'si düşük olan yaşlı nüfus sayısının yüksekliği nedeni ile KBY'nin bu düzeylerden daha fazla olduğu düşünülmektedir. Sonuç olarak dünyada 500 milyondan fazla KBY olduğu tahmin edilmektedir [18, 19].

Kronik böbrek hastalıklarının oluşumunda birçok etiyolojik faktör söz konusudur. Bunlar arasında, diyabetik nefropati ve hipertansiyon bütün dünyada ilk siralarda gelir. KBH'nin diğer etiyolojik nedenleri arasında ise primer glomerüler hastalıklar, tübülointertisyal hastalıklar, renal vasküler hastalıklar, kronik üriner sistem tıkanıklı̆̆ı, kollojen doku hastalıkları ve bazı metabolik hastalıklar sayılabilir [20].

Etiyolojik nedenlerden bağımsız olarak nefron kayıpları sonucu sağlam nefronların adaptasyon sürecinde hipertrofiye uğrayarak klirens yükleri artmaktadır. Nefron uyumundaki bu süreçte sağlam nefronlarda intrakapiller basınç artışı söz konusudur. Bu basınç artışı sonucu nefronlardan filtre olan protein kaybını da artırarak proteinüri’ye sebep olmaktadır. Proteinüri'nin şiddeti böbrek hasarı ile doğru orantılı olup sebep-sonuç ilişkisi olarak da değerlendirilebilir. Ayrıca renin anjiotensin sisteminin aktivitesi de artar. Anjiotensin ve diğer sitokinlerin bu bölgedeki artışı, glomerüllerin skleroza gitmesine neden olur. Sklerozu hızlandıran faktörler, kronik böbrek hastalı̆̆ının progresyonunu da artırır. Proteinüri, hipertansiyon ve hiperlipidemi başlıca risk faktörlerinden sayılabilir [21].

\subsection{Diyaliz Hastalarının Yaşadığı Sıkıntılar}

Hemodiyaliz hastaları kronik böbrek yetmezliği hastalığına bağlı olarak uyum sorunu, anksiyete bozukluğu, depresyon ve intihar, cinsel işlev bozukluğu, ekonomik ve sosyal sorunlar gibi yaşamlarını ve hastalıklarının seyrini etkileyen pek çok sorunla karşı karşıya kalmaktadır [22].

Hemodiyaliz hastalarında en sık görülen psikolojik problemlerden biri sürekli depresif mizaç, benlik saygısı düşüklüğü ve ümitsizlik hisleri ile beliren depresyondur [22]. Sağlıklarını, fiziksel güçlerini, cinsel potansiyellerini, özerkliklerini, çalışma yeteneklerini kaybedebilecekleri endişesinin olması hastalarda depresyona yol açar ve kronik hastalığın seyrini diyete uymama, tedaviyi reddetme, sosyal izolasyon, uyku bozuklukları, üzüntü ve keder gibi sebeplerle olumsuz yönde etkiler [23]. Cinsel işlev bozukluğu, hemodiyaliz hastalarında, her iki cinste de yaygın olarak görülmektedir. Hemodiyaliz hastalarında cinsel sorunlar organik faktörlerle hastalığın psikolojik ve psiko-sosyal komplikasyonlarının etkileşimi sonucu ortaya çıkmaktadır. Endokrin değişiklikleri, çeşitli ilaçlar, genel fiziksel durum, aile içi sosyal rollerdeki değişimler, depresyon ve psiko-sosyal faktörler cinsel işlevleri bozmaktadır [23]. 
Kronik bir hastalığın tanısı, hastalığa bağlı olarak ortaya çıkan değişiklikler hastalarda psikolojik sorunlara ve uyum güçlüklerine sebep olabilmektedir. Kronik hastalığa karşı verilen farkl1 duygusal tepkilerin sıklığı ve işlevi, hastaların hastalık hakkındaki anlayışları ve hastaların baş etme çabaları hastanın hastalığa uyum sürecini etkilemektedir [24]. Kronik bir hastalığın varlığı hastaların sosyal etkileşimleri üzerinde her zaman sorun yaratmıştır. Kronik hastalık tanısından sonra hasta normal sosyal ilişkilerini sürdürmede güçlük çeker, diğer insanların ona acıma ve onu reddetme durumuyla karşılaşabilir. Bunun sonucunda hasta sosyal aktivitelerini kısıtlayarak daha içe dönük bir hayat tarzı eğilimini benimseyebilir. Hasta birey çevresine uyum sağlamakta zorlandığı gibi hastanın çevresi de ortaya çıkan bu yeni duruma uyum sağlamada güçlük çeker [25]. Gelişen cerrahi tekniklerle birlikte son yıllarda böbrek nakli sık uygulanabilir hale gelmiştir. Diyalizin pahalı ve yaşam süresini kısaltan bir tedavi yöntemi olması gibi etkenler klinisyenleri organ nakli yapmaya yöneltmektedir [26]. Yapılan çoğu araştırmaya göre organ naklinin, diyaliz tedavisine kıyasla hastaların fiziksel ve ruhsal açıdan yaşam kalitesini arttırdığını göstermektedir [27, 28].

Organ nakli tüm bu olumlu özelliklerinin yanı sıra fiziksel ve ruhsal birtakım sorunları da beraberinde getirmektedir. Bu hastalar, anksiyete, majör depresyon, intihar, kronik organik beyin sendromu yönünden riskli grup olarak değerlendirilebilirler. Bu hastalarda ayrıca fiziksel ve ruhsal süreçlerle bağlantılı olarak vücut imajı değişikliği ve cinsel bozukluklara sık rastlanmaktadır [23]. Aile içinde bir bireyin hemodiyaliz tedavisi alması, çoğu zaman ailede ekonomik sorunların ortaya çıkmasına sebep olmaktadır. Hastaların yaklaşık 2/3'ü kronik böbrek yetmezliği tanısı almadan önce çalıştığı işini kaybetmektedir [29]. Hasta bireyin işini kaybetmesi ve iş gücü kaybına uğramasının yanı sıra tedavi masrafları ve bazı aileler için diyaliz merkezlerinin bulunduğu büyük kentlerde yaşama zorunluluğu da aileye ekonomik sorunlar yaşatmaktadır [30].

Diyaliz hastalarında merkezi sinir sistemini etkileyen, çeşitli toksik metabolik faktörlere bağlı olarak organik beyin sendromları gelişme riski oldukça yüksektir. Pek çok hemodiyaliz hastası, diyaliz günü yaklaştıkça, zihin işlevlerinde yavaşlama ve karışıklık geliştiğini, unutkanlık, dikkatini toplayamama ve sinirlilik ortaya çıktığını ifade eder [23].

Diyaliz hastalarında görülen en ciddi ve ölümcül diğer bir organik ruhsal bozukluk diyalize bağlı beyin tutulumu olarak açıklanır. İlk kez 1972'de tanımlanan tabloya göre denge ve konuşma bozukluğu, konuşamama, düzensiz kas kasılmaları, bölgesel nöbetler, kollarda bacaklarda kuvvet azalması, delirium nöbetleri, giderek paranoid sanrılar ve demans ortaya çıkar. Genellikle iki yıldan fazla diyaliz hizmeti alan hastalarda görülür ve ölümcüldür [23, 30]. Hipertansiyon, göğüs ve sırt ağrıs1, aritmi, kas krampları, bulant1-kusma ve hava embolisi, hemodiyaliz tedavisine bağlı diğer komplikasyonlardır [31].

Kronik böbrek yetmezliği nedeniyle hemodiyaliz uygulanan hastalarda yorgunluk önemli bir bulgudur [32]. Hemodiyaliz uygulanan hastaların yaklaşı olarak yarısı belirli bir derecede yorgunluk hissetmekte ve enerji kaybı yaşamaktadır. Daha birçok kronik hastalıkta olduğu gibi, kronik böbrek yetmezliği nedeni ile hemodiyaliz uygulanan bireylerde de yorgunluk önemli bir belirti olarak kabul edilir. Kronik böbrek yetmezliği tablosunda kardiyovaskuler, hematopoetik, metabolik ve endokrin sistem fonksiyonlarının etkilenmesi ile bireyler önemli ölçüde yorgunluk hissetmekte, bunun sonucunda ise, biyolojik ve psikolojik sorunlar ortaya çıkmakta, sosyal ilişkiler ve mesleki yaşam olumsuz yönde etkilenebilmektedir [33, 34]. 


\section{Materyal ve Yöntem}

\section{1. Örneklem}

Bu çalı̧̧ma Bitlis Devlet Hastanesi'nde ve Tatvan Devlet Hastanesi'nde diyaliz ünitesine rutin olarak bağlanan hastalar arasında yapılmıştır. Hastalar bilgilendirildikten sonra araştırmaya katılmaya istekli olan 39 erkek ve 31 kadın olmak üzere toplam 70 hasta katılmıştır. Hastalara toplam 26 soru sorulmuştur.

\section{2. İstatistiksel Analiz}

Elde edilen verilerin istatistiksel olarak değerlendirilmesi IBM SSPS Statistics 20® Paket Programıyla Ki-kare ve Sıklık testleri uygulanarak yapılmıştır. $p<0,05$ değeri istatistiksel olarak anlamlı kabul edilmiştir. Hastaların yaş ortalamaları aritmetik ortalaması alınarak hesaplanmış, sonuç ortalama \pm standart hata olarak verilmiştir.

\section{Bulgular}

Çalışmada 70 hasta değerlendirmeye alındı. Hepsi haftada 3 kez 4'er saat diyalize girmekte olup, ihmal edilebilir rezidüel renal fonksiyona sahipti. Ankete katılan hastaların \%20.0'si 0-1 y1l, \%27.1'i 2-3 y1l, \%24.3'ü 4-5 yıl, \%8.6'sı 6-7 yıl, \%11.4'ü 8-9 yıl, \%4.3'ü 10-11 yıl ve \%4,3'ü de 14-15 yıl arasında diyalize bağlanmaktadırlar. Ankete katılan hastaların demografik özelliklerine bakıldığında \%55.7'si bay, \%44.3'ü kadındır. \%68.6'sı evli, \%31.4'ü de bekârdır. Hastaların en küçüğü 14, en büyüğü de 78 yaşında olmak üzere genel yaş ortalaması $43.8 \pm 17.1$ 'dir. Bu hastaların \%34.3'ü okur-yazar değildir, \%14.3'ü ilkokul, \%25.7'si ortaokul, \%12.9'u lise ve \%12.9'u da yüksekokul mezunudur.

Ankete katılan hastaların diğer bazı özelliklerine bakıldığında, \%22.9'una maddi destek, \%48.6'sına ulaşımda kolaylık, \%2.9'una hem maddi hem de ulaşımda kolaylık sağlanmıştır. \%25.4'üne ise hiçbir kolaylık sağlanmamıştır. Hastalıklarını öğrendikten sonra hastaların \%27.1'i profesyonel olarak destek almış, \%72.9'u da profesyonel olarak destek almamıştır. \%48.6'sı hiçbir zaman sıkıntı yaşamamış, \%32.9'u bazen, \%12.9'u çoğu zaman, \%5.7'si ise her zaman sıkıntı, dışlanma durumu yaşamıştır. \%32.9'u hiçbir zaman ailesini zor durumda bıraktığını düşünmemiş, \%44.3'ü bazen, \%14.3'ü çoğu zaman, \%8.6'sı da her zaman ailesini zor durumda bıraktığını düşünmüsstür. \%54.3'ü kendisini ailesine karş1 yeterli bulmakta, \%45.7'si ise yeterli bulmamaktadır. \%84.3'ünün yapmak isteyip de yapamadığ nakli için yeterli girişimlerde bulunduğunu düşünmekte, \%30.0'u ise yeterli girişimlerde bulunduğunu düşünmemektedir.

Hastaların cinsiyetlerine göre yaşadıkları sıkıntılar arasında fark olup olmadığını belirlemek amacıyla cinsiyet ile bazı sıkıntı parametreleri karşılaştırılmış ve Çizelge 1'de sunulmuştur. 
Çizelge 1. Cinsiyet ile bazı sıkıntı parametrelerinin karşılaştırılması ( $\mathrm{n}=70)$

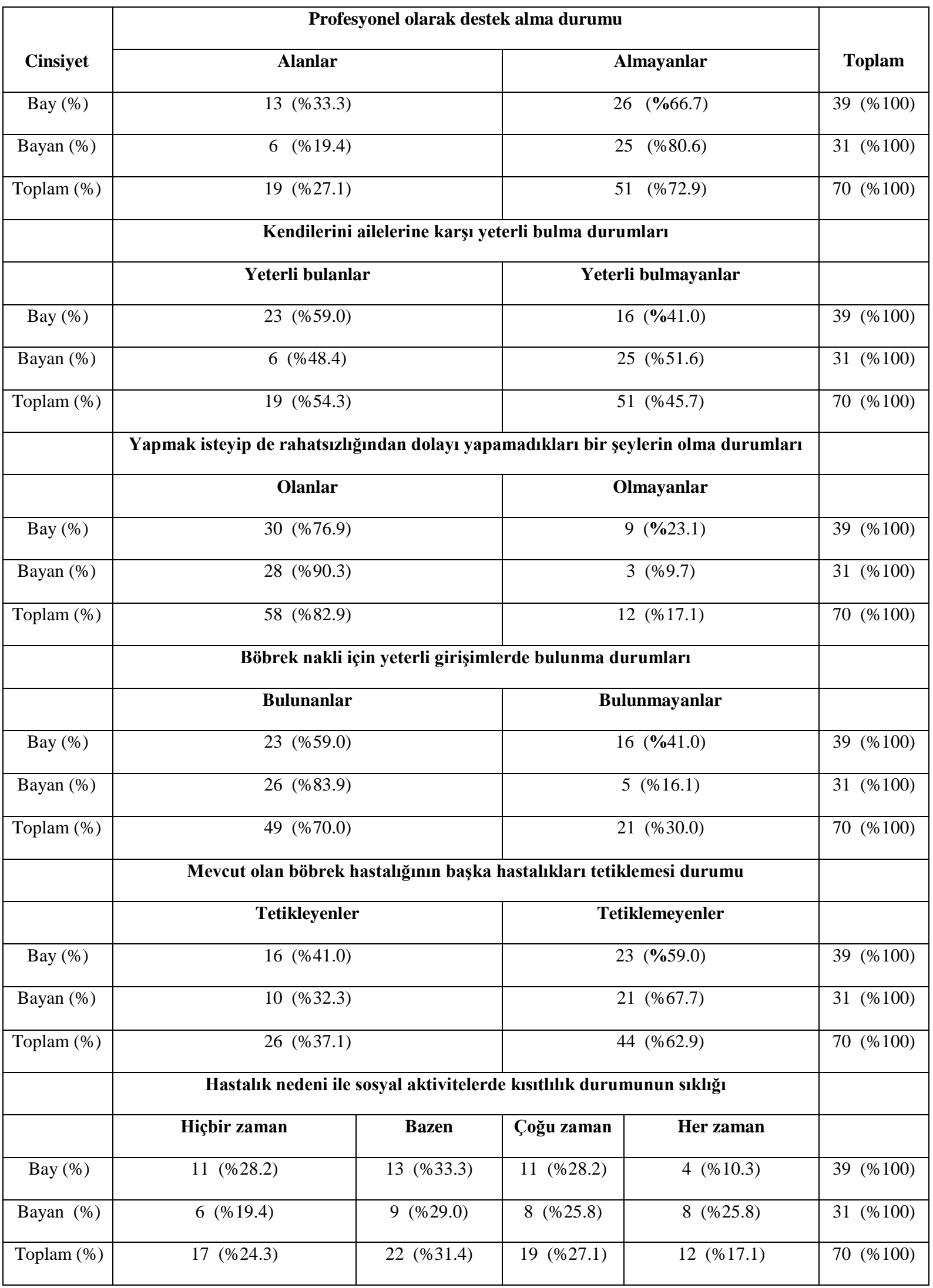


Çizelge 1'deki sonuçlara göre, cinsiyet ile profesyonel olarak destek alma durumları, cinsiyet ile hastaların kendilerini ailelerine karşı yeterli bulma durumları, cinsiyet ile hastaların yapmak isteyip de hastalıklarından dolayı yapamadıkları bir ideallerinin olma durumları, cinsiyet ile böbrek nakli için yeterli girişimlerde bulunma durumları, cinsiyet ile mevcut olan böbrek hastalığının başka hastalıkları tetiklemesi ve cinsiyet ile hastalığın getirdiği sosyal aktivitelerde kısıtlılık durumları karşılaştırılarak, anlamlı bir ilişki bulunamamıştır ( $\mathrm{p}>0.05$ ).

Hastaların medeni durumlarına göre yaşadıkları sıkıntılar arasında fark olup olmadığını belirlemek amacıyla da, yine medeni durum ile bazı sıkıntı parametreleri karşılaştırılmış ve Çizelge 2'te sunulmuştur.

Çizelge 2. Medeni durum ile bazı sıkıntı parametrelerinin karşılaştırılması ( $\mathrm{n}=70)$

\begin{tabular}{|c|c|c|c|c|c|}
\hline \multirow{2}{*}{ Medeni durum } & \multicolumn{4}{|c|}{ Böbrek nakli için yeterli girişimlerde bulunma durumu } & \multirow{2}{*}{ Toplam } \\
\hline & \multicolumn{2}{|c|}{ Bulunanlar } & \multicolumn{2}{|c|}{ Bulunmayanlar } & \\
\hline Evli (\%) & \multicolumn{2}{|c|}{$33(\% 68.8)$} & \multicolumn{2}{|c|}{$15(\% 31.2)$} & $48 \quad(\% 100)$ \\
\hline Bekâr (\%) & \multicolumn{2}{|c|}{$16(\% 72.7)$} & \multicolumn{2}{|c|}{$6(\% 27.3)$} & $22(\% 100)$ \\
\hline \multirow[t]{3}{*}{ Toplam (\%) } & \multicolumn{2}{|c|}{$49(\% 70.0)$} & \multicolumn{2}{|c|}{$21(\% 30.0)$} & $70(\% 100)$ \\
\hline & \multicolumn{4}{|c|}{$\begin{array}{l}\text { Hastalık nedeni ile ailesinin maddi destek sağlarken sıkıntı yaşama durumunun } \\
\text { sıklığı }\end{array}$} & \\
\hline & Hiçbir zaman & Bazen & Çoğu zaman & Her zaman & \\
\hline Evli (\%) & $19(\% 39.6)$ & $20(\% 41.7)$ & $6(\% 12.5)$ & $3(\% 6.2)$ & $48(\% 100)$ \\
\hline Bekâr (\%) & $6(\% 27.3)$ & $12(\% 54.5)$ & $2(\% 9.1)$ & $2(\% 9.1)$ & $22(\% 100)$ \\
\hline \multirow[t]{3}{*}{ Toplam (\%) } & $25(\% 35.7)$ & $32(\% 45.7)$ & $8(\% 11.4)$ & $5(\% 7.1)$ & $70(\% 100)$ \\
\hline & \multicolumn{4}{|c|}{ Hastalık nedeni ile sosyal aktivitelerde kısıtlılık durumunun sıklığı } & \\
\hline & Hiçbir zaman & Bazen & Çoğu zaman & Her zaman & \\
\hline Evli $(\%)$ & $12(\% 25.0)$ & $15(\% 31.2)$ & $11(\% 22.9)$ & $10(\% 20.8)$ & $48(\% 100)$ \\
\hline Bekâr (\%) & $5(\% 22.7)$ & $7(\% 31.8)$ & $8(\% 36.4)$ & $2(\% 9.1)$ & $22(\% 100)$ \\
\hline \multirow[t]{3}{*}{ Toplam (\%) } & $17(\% 24.3)$ & $22(\% 31.4)$ & $19(\% 27.1)$ & $12(\% 17.1)$ & $70(\% 100)$ \\
\hline & \multicolumn{4}{|c|}{ Hastalık nedeni ile aile içi ilişkilerde sorun yaşama durumunun sıklığı } & \\
\hline & Hiçbir zaman & Bazen & Çoğu zaman & Her zaman & \\
\hline Evli (\%) & $24(\% 50.0)$ & $15(\% 31.2)$ & 7 (\%14.6) & $2(\% 4.2)$ & $48(\% 100)$ \\
\hline Bekâr (\%) & $11(\% 50.0)$ & $9(\% 40.9)$ & $0(\% 0.0)$ & $2(\% 9.1)$ & $22(\% 100)$ \\
\hline Toplam (\%) & $35(\% 50.0)$ & $24(\% 34.3)$ & $7(\% 10.0)$ & $4(\% 5.7)$ & $70(\% 100)$ \\
\hline
\end{tabular}

Çizelge 2'deki sonuçlara göre hastaların medeni durumu ile böbrek nakli için yeterli girişimlerde bulunma durumları, medeni durum ile hastalık nedeni ile ailesinin maddi destek sağlarken sıkıntı yaşama durumları, medeni durum ile hastalık nedeni ile sosyal aktivitelerde kısıtlılık durumları ve medeni durum ile hastalık nedeni ile aile içi ilişkilerde sorun yaşama durumları karşılaştırılarak, anlamlı bir ilişki bulunmamıştır ( $\mathrm{p}>0.05)$. 


\section{Tartışma}

Hemodiyaliz hastaları kronik böbrek yetmezliği hastalığına bağlı olarak uyum sorunu yaşarken, bunun yanında birçok problemle de baş etme çabası içerisindedirler. Hemodiyaliz hastaları üzerinde yapılan birçok araştırma sonucuna göre diyaliz hastalarında anksiyete düzeyinin yüksek olduğu açıklanmıştır [30]. Bu bağlamda 62 hasta üzerinde yapılan bir araştırma sonucunda da benzer bulguya rastlanmıştır. Söz konusu çalışmaya göre hastaların anksiyete puan ortalamaları toplumumuz için saptanan puanın üzerindedir [35]. Türkiye'de bir çalışmada 37'si hemodiyaliz ve 27'si sürekli ayaktan periton diyalizi uygulanan hastalar anksiyete yönünden karşılaştırılmıştır. Araştırma sonucunda her iki grup hastanın sürekli anksiyete düzeyinin normal popülasyondan fazla olduğunu, hemodiyaliz hastalarının ise sürekli periton diyalizi uygulanan hastalara göre daha belirgin şekilde sürekli anksiyete yaşadıkları ortaya konmuştur. $\mathrm{Bu}$ farkın nedeni ise hemodiyaliz tedavisinde hastanın haftada 2-3 kez 4-5 saat süreyle makineye bağımlı kalması, diyet ve sıvı kısıtlaması olması, fiziksel durumun gün içinde değişkenlik göstermesi olarak açıklanmıştır. Sürekli ayaktan periton diyaliz uygulaması ise hastayı makineye bağlı hale getirmemekte, evde uygulanabilmekte ve hastaların sıvı ve biyokimya değerinde ani değişikliklere yol açmamaktadır [36].

Türkiye'de hemodiyaliz hastalarında depresyon ve intihar düşüncesi düzeyleri ile bunlara etkili olabilecek faktörleri araştırmayı amaçlayan ve 30'u kadın, 63'ü erkek olmak üzere 93 hasta üzerinde yapılan bir çalışmada hemeodiyaliz hastalarında depresyon ve intihar düşüncesindeki artışa yüksek orandaki umutsuzluk ile azalmış olarak algılanan aile ve arkadaş desteklerinin rolü olduğu ortaya çıkmıştır [37]. Çalışmada hastalıklarını ilk öğrendiklerinde hastaların \%18.6'sının umutsuzluğa kapıldığı, \%15.7'sinin gelecek kaygıS1 yaşadığı, \%8.6'sının inanamadığı, \%18.6'sının kabullenemediği, \%8.6'sının hiçbir şey hissetmediği, \%2.9'unun şok benzeri duygu yaşadığ1, \%10.0'unun çok üzüldüğü, \%15.7'sinin kabullendiği ve \%1.4'ününde hastalığının ne olduğunu merak ettiği belirlenmiştir.

Kronik yorgunluk sendromunu tanımlamak adına yapılan çalışmalar neticesinde tablonun nonspesifik virüs enfeksiyonlarından çok enfeksiyoz mononükleoz sonrası görülebildiği, bir aydan uzun yorgunluk tablosunun \%73, altı aydan uzun yorgunluk tablosunun $\% 9$ sikl1kta olduğu bildirilmiştir [38]. Kronik böbrek yetmezliği nedeni ile hemodiyaliz uygulanan bireylerde birçok biyopsiko-sosyal faktör yorgunluğa katkıda bulunmaktadır. Yapılan çalışmalara göre hemodiyaliz hastalarında yorgunluğun önemli bir belirti olduğu ve bireyin yaşam kalitesinin önemli derecede etkilendiği saptanmıştır. Hemodiyaliz hastalarının çalışma, boş zamanlarını değerlendirme, beslenme alışkanlığ , seksüel aktiviteleri, yaşamdan zevk alma, aile ve arkadaş ilişkilerinin olumsuz yönde etkilendiği ve bu durumun yorgunlukla yakından ilişkili olduğu ortaya koyulmuştur [39].

\section{Kaynaklar}

1. Erek E, 2005. Nefroloji. Nobel Tip Kitapevleri, 5. Bask1, 463s, Ankara.

2. Akpolat T, Utaş C, 1997. Hemodiyaliz Hekimi El Kitabı. Erciyes Üniversitesi Matbaası, Kayseri, Bölüm 1-3, 22.

3. Selçuk NY, 1999. Renal Replasman Tedavileri İçin Hasta Seçme Kriterleri, Türk Nefroloji Dergisi, 2: 51-55.

4. Kotanko P, Kuhlmann KM, Levin WN, 2010. Hemodialysis: Principles and Techniques, in Comprehensive Clinical Nephrology, Edited by Fleoge J., Johnson RJ., Freehally J. Elsevier Limited, 4nd edition Philadelphia, Pennsylvania, USA, 1053-1059.

5. Eczacıbaşı-Baxter, 2006. Periton Diyalizi Tedavisi Eğitimi. http://www.eczacibasibaxter.com.tr/DynamicPage.aspx?Id=21 (Erişim Tarihi: 29.08.2014). 
6. Sorkin MI, Diaz-Buxo JA, 1994. Physiology of Peritoneal Dialysis, in Handbook of Dialysis. Edited by Daugirdas JT, Ing TS, Little Brown and Company, Boston, 92-120.

7. Erek E, Süleymanlar G, 1996. Renal Hastalıklara İlişkin Renal Fizyoloji, Temel İç Hastalıkları. Editörler: Biberoğlu K, Akalın S, Süleymanlar G, Cilt 1, Güneş Kitap Evi, Ankara, 685-920.

8. Aydın Z, 2001. Sürekli Ayaktan Periton Diyalizi, Hemodiyaliz Hemşire El Kitabı (3. Baskı), Güzel Sanatlar Matbaas1, İstanbul, 126-160.

9. Remuzzi G, Bertoni T, 1998. Pathophysiology of Progressive Nephrophaties. New England Journal of Medicine, 339: 1448-1156.

10. Baysal A, Aksoy M, Bozkurt N, Merdol T, Pekcan G, Keçecioğlu S, Besler HT, Mercanlıgil S, 2002. Diyet El Kitabı, 4. Baskı, Hatipoğlu Yayınları, 592s, Ankara.

11. Anand S, Shivashankar R, Ali MK, Kondal D, Binukumar B, Montez-Rath ME, Ajay VS, Pradeepa R, Deepa M, Gupta R, Mohan V, Venkat Narayan KM, Tandon N, Chertow GM, Prabhakaran D. Prevalence of chronic kidney disease in two major Indian cities and projections for associated cardiovascular disease. Kidney Int. 2015 Mar 18. doi: 10.1038/ki.2015.58. [Epub ahead of print].

12. Süleymanlar G, Utaş C, Arınsoy T, Ateş K, Altun B, Altıparmak MR, Ecder T, Yılmaz ME, Çamsari T, Başçı A, Odabaş AR, Serdengeçti K, 2011. A Population-Based Survey of Chronic Renal Disease in Turkey--the CREDIT Study. Nephrol. Dial. Transplant, 26 (6): 1862-1871.

13. Süleymanlar G, Serdengeçti K, Altiparmak MR, Jager K, Seyahi N, Erek E, 2011. Trends in Renal Replacement Therapy in Turkey, 1996-2008. Am. J. Kidney Dis. 57 (3): 456-465.

14. Heimbürger O, Qureshi AR, Blaner WS, Berglund L, Stenvinkel P, 2000. Hand-Grip Muscle Strength, Lean Body Mass and Plasma Proteins as Marker of Nutritional Status in Patients with Chronic Renal Failure Close to Start to Dialysis Therapy. Am. J. Kidney Dis., 36: 1213-1225.

15. Yenicesu M, 2009. Hemodiyalizde Damara Ulaşım. Hekimler İçin Hemodiyaliz Kaynak Kitabı. Ed: Arık N, Ateş K, Süleymanlar G, Tonbul HZ, Türk S, Yıldız A, Ankara, Güneş Tıp Kitabevi.

16. Özdemir Ü, Taşcı S, 2013. Kronik Hastalıklarda Psikososyal Sorunlar ve Bakım. Erciyes Üniversitesi Sağlık Bilimleri Fakültesi Dergisi, 1 (1): 57-7.

17. KDIGO BP Work Group. KDIGO clinical practice guideline for the management of blood pressure in chronic kidney disease. Kidney inter., Suppl, 2012; 2: 337-414.

18. El Nahas M, 2005. The Global Challenge of Chronic Kidney Disease. Kidney Int., 68 (6): 29182929.

19. Obrador GT, Pereira BJG, 2012. Epidemiology of Chronic Kidney Disease and Screening Recommendations. Up To Date, 19: 2.

20. Stein A, Wild J, 2002. Kidney Failure Explained (Class Helath), 136p, London, UK.

21. Utaş C, Süleymanlar G, 2002. Nefroloji El Kitabı. 3. Basım, Nobel Tıp Kitabevi, 344s. İstanbul.

22. Sezer MT, 2001. Psikiyatrik Sorunlar, Hemodiyaliz Hekimi El Kitabı. Editörler: Tekin Akpolat, Cengiz Utaş. İkinci baskı, Anadolu Yayıncılık. Kayseri.

23. Özkan S, 1993. Psikiyatrik Tip Konsültasyon-Liyezon Psikiyatrisi. Roche, 296s. İstanbul.

24. Duyan V, 1997. Sosyal Grup Çalışması Uygulamasının Ortopedi Hastalarının Kişisel Ve Sosyal Uyum Düzeylerine Etkisi. Aydınlar Matbaacılık, 168s. Ankara.

25. Mutlu E, 2007. Hemodiyaliz Hastalarının Sosyo-Demografik Özellikleri, Sosyal Destek Kaynakları ve Hastalık Sürecinin Benlik Saygısına Etkisi. Hacettepe Üniversitesi, Sosyal Bilimler Enstitüsü, Sosyal Hizmet Anabilim Dalı, Yüksek Lisans Tezi, 132s. Ankara.

26. Baykan H, Yargıç İ, 2012. Depression, anxiety disorders, quality of life and stres coping strategies in hemodialysis and continuous ambulatory peritoneal dialysis patients. Bulletin of Clinical Psychopharmacology, 22 (2): 167-76. 
27. Sağduyu A, Şentürk V, Sezer S, Emiroğlu R, Özel S, 2006. Hemodiyalize giren ve böbrek nakli yapılan hastalarda ruhsal sorunlar, yaşam kalitesi ve tedaviye uyum. Türk Psikiyatri Dergisi, 17 (1): 22-31.

28. Çetinkaya S, Nur N, Ayvaz A, Özdemir D, 2008. Bir üniversite hastanesinde hemodiyaliz ve sürekli ayaktan periton diyalizi hastalarında depresyon, anksiyete düzeyleri ve stresle başa çıkma tutumları. Nöropsikiyatri Arşivi, 45: 78-84.

29. Utaş C, Akpolat T, 2001. Böbrek Yetmezliği: Genel Bilgiler, Hemodiyaliz Hekimi El Kitabı. Editörler: Tekin Akpolat, Cengiz Utaş. İkinci bask1, Anadolu Yayıncılık, 1-14. Kayseri.

30. Cimilli C, 1994. Hemodiyalizin Psikiyatrik Yönleri. Türk Nefroloji Diyaliz Ve Transplantasyon Dergisi, 3 (3): 88-92.

31. Kadayıfçı A, 2003. Dahiliye/UTS Uzmanlar Tus Serisi. Dördüncü Basım, Atlas Yayıncılık, 620s, Ankara.

32. Aslan FE, Şelimen D, Turhal NS, Karamanoğlu A, 2001. Onkoloji Hemşireliği Hizmet Içi Eğitim Kursu. Onbir Matbaac1l1k, 15-49, İstanbul.

33. Murray EC, Deighan C, Geddes C, Thomson PC, 2014. Taurolidine-citrate-heparin catheter lock solution reduces staphylococcal bacteraemia rates in haemodialysis patients. QJM, 107 (12): 9951000.

34. Öbek A, 1990. İç Hastalıkları, 4. Baskı, Güneş Kitabevi, 907s, Bursa.

35. Özgür B, Kürşat S, Aydemir Ö, 2003. Hemodiyaliz Hastalarında Yaşam Kalitesi ile Anksiyete ve Depresyon Düzeyleri Yönünden Değerlendirilmesi. Türk Nefroloji, Diyaliz Ve Transplantasyon Dergisi, 12 (2): 113-116.

36. Erengin N, Keçecioğlu N, Güven M, Sarıkaya M, Tuncer M, Özcan S, 1993. Hemodiyaliz ve Sürekli Ayaktan Periton Diyalizi Uygulanan Hastaların Yetiyimi, Depresyon ve Anksiyete Yönünden Karşılaştırılması. Türk Nefroloji, Diyaliz ve Transplantasyon Dergisi, 3: 137-140.

37. Cöngevel M, Evrenkaya T, Ebrinç S, Atasuyu MA, Çetin M, Tülbek MK, 1999. Kronik Hemodiyaliz Hastalarında İntihar Düşüncesi ve Depresyonu Etkileyen Faktörler. Gülhane Tıp Dergisi, 41 (4): 450-458.

38. Lloyd AR, 1998. Chronic fatique and chronic fatique syndrome: Shifting boundaries and attributions. Am J Med, 105 (3A): 7-10.

39. Carpentino LJ, 1989. Nursing Diagnosis Application to Clinical Practice, Third edition, JB, Lippincott Company, 1016s, Philadephia.

Geliş Tarihi: 22/04/2015

Kabul Tarihi: 18/06/2015 